\title{
Pelatihan dan Pendampingan Pembuatan Media Simulasi Praktikum IPA SMP dengan Program Simulasi Phet
}

\author{
Rai Sujanem ${ }^{1 *}$, Erwan Sutarno ${ }^{2}$, I Gede Aris Gunadi ${ }^{3}$ \\ 1,2,3 Fakultas MIPA Universitas Pendidikan Ganesha
}

A R T I C L E I N F O

Article history:

Received 20 December 2018

Received in revised form 15 January 2019

Accepted 30 January 2019

Available online 27

February 2019

\section{Kata Kunci:}

media simulasi, praktikum

IPA, program phet

Keywords:

media simulation, science practicum, phet program

\begin{abstract}
A B S T R A K
Tujuan kegiatan pelatihan ini adalah sebagai berikut. 1) Meningkatkan pengetahuan dan keterampilan guru-guru IPA SMP untuk membuat media simulasi praktikum IPA dengan program PhET. 2) Guru-guru IPA SMP dapat mengimplementasikan media simulasi praktikum IPA dengan program PhET dalam proses pembelajaran IPA. Peserta pelatihan adalah guru-guru IPA SMPN 1 Sukasada, SMP Negeri 1, 2, 3, 4, 5 Singaraja, dan SMP Lab Undiksha Singaraja. Jumlah peserta adalah 15 orang. Prosedur kegiatannya melalui pelatihan dan pendampingan pembuatan media simulasi praktikum IPA dengan program $\mathrm{PhET}$. Hasil pelatihan menunjukkan bahwa 1) peserta pelatihan telah memiliki pengetahuan dan keterampilan untuk membuat media simulasi praktikum IPA dengan program PhET, 2) peserta pelatihan dapat mengimplementasikan media simulasi praktikum IPA dengan program PhET dalam pembelajaran di kelas. Berdasarkan uraian ini, dapat disimpulkan bahwa para peserta pelatihan telah dapat membuat media simulasi praktikum IPA dengan program PhET dan dapat mengimplementasikan dalam pembelajaran IPA di kelas.
\end{abstract}

\section{A B S T R A C T}

The purpose of this training activity were as follows. 1) Improving the knowledge and skills of junior high school science teachers to create science practice simulation media with the PhET program. 2) Junior high school science teachers can implement a science practice simulation media with the PhET program in the science learning process. The participants of this training activity were science teachers at State Junior High School 1 Sukasada, State Junior High School 1, 2, 3, 4, 5 Singaraja, and Lab Undiksha Junior High School. The number of participants was 15 people. The procedure of the activity was through training and mentoring to create a science practice simulation media with the PhET program. The training results show that 1) the training participants already have the knowledge and skills to create a science practice simulation media with the PhET program, 2) the training participants can implement a science practice simulation media with the PhET program in classroom learning. Based on this description, it can be concluded that the trainees have been able to create a science practice simulation media with a PhET program and can implement it in science learning in the classroom.

\footnotetext{
* Corresponding author.

E-mail addresses: raisujanem@yahoo.com (Rai Sujanem)
} 


\section{Pendahuluan}

Era globalisasi sekarang ini, berbagai institusi di tanah air terus mengembangkan implementasi teknologi informasi dan komunikasi yang bahasa trend-nya kita kenal dengan Information Communication Technology (ICT). ICT merupakan salah satu sub sector teknologi yang melahirkan banyak terobosan baru dalam bidang pendidikan untuk meningkatkan efisiensi dan efektivitas proses pembelajaran. Pendayagunaan ICT untuk pendidikan telah menjadi pilihan bagi berbagai institusi untuk peningkatan efisiensi dalam pembelajaran. Demikian pula dengan pendayagunaan teknologi multimedia dan perangkat ICT lainnya, dapat memanfaatkan fungsi otak kanan siswa dan memanfaatkan memori jangka panjang anak didik sambil mengasah kemampuan berfikir dan berkreasi (Firman, 2003).

Lebih lanjut menurut Permendiknas Nomor 16 Tahun 2007 ditetapkan bahwa salah satu Kompetensi Pedagogik yang harus dimiliki guru SMP/MTs adalah mampu memanfaatkan teknologi informasi dan komunikasi untuk kepentingan pembelajaran. Sementara untuk kompetensi Profesional, guru SMP/MTs harus mampu memanfaatkan ICT untuk berkomunikasi dan mengembangkan diri. Ini menunjukkan bahwa kemampuan memanfaatkan ICT bukanlah hanya menjadi monopoli bagi guru bidang ICT saja, tetapi guru SMP/MTs yang berstatus guru IPA juga wajib untuk mampu memanfaatkan ICT.

Salah satu ciri pengelolaan pembelajaran IPA (fisika) yang berkualitas di sekolah adalah terciptanya proses pembelajaran yang memperhatikan karakteristik dari fisika sebagai produk dan proses yang tercemin mulai dari tahap penyusunan perencanaan, pelaksanaan sampai pada proses evaluasi. Untuk mewujudkan kualitas pendidikan tersebut, maka peran kompetensi profesional guru fisika sangatlah penting dan mutlak diperlukan. Komitmen pemerintah untuk meningkatkan kompetensi profesional guru termasuk guru fisika di sekolah agar menciptakan pendidikan yang berkualitas ditandai dengan lahirnya beberapa kebijakan, antara lain PP No 65 Tahun 2013 Tentang Standar Proses Untuk Satuan Pendidikan Dasar dan Menengah. Berdasarkan peraturan menteri pendidikan dan kebudayaan nomor 65 tahun 2013, pembelajaran diharapkan dapat berlangsung secara interaktif, inspiratif, menyenangkan, menantang, memotivasi peserta didik untuk berpartisipasi aktif, serta memberikan ruang yang cukup bagi prakarsa, kreativitas, dan kemandirian sesuai dengan bakat, minat dan perkembangan fisik serta psikologis peserta didik.

Dalam abad $21 \mathrm{ini}$, tantangan pelaksanaan pendidikan di sekolah semakin berat. Setidaknya ada tiga aspek yang sangat mempengaruhi dunia pendidikan saat ini, yaitu aspek globalisai, teknologi dan inovasi, dan bagaimana cara siswa belajar. Salah satu aspek dari $21^{\text {st }}$ century skill adalah learning and innovation skill yang mencakup keterampilan berpikir kritis (critical thinking skill). Keterampilan berpikir kritis meliputi kemampuan individu untuk mengajukan pertanyaan untuk memecahkan masalah, menganalisis dan mengevaluasi alternatif dari berbagai sudut pandang, dan merefleksikan secara kritis keputusan dan proses (www.21stcenturyskills.org).

Berdasarkan wawancara dengan guru-guru IPA SMP di kota Singaraja, terungkap bahwa kegiatan laboratorium IPA bidang fisika masih sangat terbatas. Ada beberapa hal penyebab keterbatasan kegiatan laboratorium ini, diantaranya keterbatasan ruang lab, keterbatasan alat lab, alat lab yang mengalami kerusakan, bahkan ruang lab di pakai ruang kelas belajar. Dengan demikian, guru-guru IPA (khususnya fisika) cenderung mengelola pembelajarannya secara teoritis dan matematik daripada penerapan pendekatan keterampilan proses melalui kegiatan penyelidikan atau kerja ilmiah. Kegiatan laboratorium merupakan tempat untuk mengaplikasikan teori keilmuan, pengujian teoritis, pembuktian uji coba, penelitian, dan sebagainya dengan menggunakan alat bantu yang menjadi kelengkapan dari fasilitas dengan kuantitas dan kualitas yang memadai (Depdiknas, 2002).

Salah satu upaya untuk mengatasi ketersediaan ala-alat laboratorium berupa KIT fisika dan media pembelajaran yang sangat terbatas yang dimiliki sekolah adalah melalui pemanfaatan ICT. Finkelstein (2005) mengatakan bahwa komputer dapat digunakan untuk menunjang pelaksanaan praktikum fisika, baik untuk mengumpulkan data, menyajikan, dan mengolah data. Selain itu, komputer juga dapat digunakan untuk memodifikasi eksperimen dan menampilkan eksperimen lengkap dalam bentuk virtual yang disebut "Model Laboratorium Maya atau Virtual Laboratory Model (VLM)". Namun demikian, kemajuan teknologi komunikasi dan informasi sangat pesat dan telah merambah banyak aspek kehidupan manusia, belum banyak dimanfaatkan oleh fihak sekolah dalam kegiatan pembelajaran. Pemanfaatan teknologi informasi, khususnya pemanfaatn komputer di kalangan institusi pendidikan pada berbagai jenjang dan jenis nampaknya masih belum merata, kecuali pada perguruan tinggi umumnya telah akses dengan teknologi internet ini. Pada jenjang dan jalur pendidikan lain seperti SMA dan SMP, di mana proses belajarnya relatif masih konvensional (tatap muka), yang sesungguhnya sudah tidak lagi mampu memenuhi kebutuhan pendidikan untuk masyarakat yang semakin kompleks, memerlukan inovasi dan media yang mampu menangulanginya. Salah satu VLM adalah PhET (Physics Education Technology. PhET merupakan salah satu softwere pendidikan yang berisi simulasi suatu gejala atau fenomena fisis 
yang sesuai dengan perkembangan teknologi pembelajaran. PhET dikembangkan oleh Universitas Colorado di Boulder Amerika (University of Colorado at Boulder) dalam rangka menyediakan simulasi pengajaran dan pembelajaran Fisika berbasis laboratorium maya (virtual laboratory) yang memudahkan guru dan siswa jika digunakan untuk pembelajaran di ruang kelas. Simulasi PhET sangat mudah untuk digunakan. Simulasi ini ditulis dalam Java dan Flash dan dapat dijalankan dengan menggunakan web browser baku selama plug-in Flash dan Java sudah terpasang. Dengan kata lain, simulasi-simulasi PhET merupakan simulasi yang ramah pengguna.

Berdasarkan permasalahan fasilitas media yang dihadapi guru-guru, maka saya memberikan alternatif solusi dengan VLM. VLM merupakan objek multimedia interaktif yang kompleks dan termasuk bentuk digital baru, dengan tujuan pembelajaran implisit atau eksplisit. Penerapan Laboratorium Maya dalam pembelajaran fisika dapat dilatihkan kemampuan berpikir (thinking skill), science process skill, communication skill, ICT skill, dan interpretation skill. Salah satu VLM yang berkembang pesat pada saat ini khususnya pada pembelajaran fisika adalah "PhET Simulation Interactive" yang dikembangkan oleh Universitas Colorado di Amerika Serikat (www.phet.colorado.edu). PhET (Physics Education Technology), Simulation Interactive dapat memberikan banyak kebebasan kepada siswa untuk melakukan kegiatan penyelidikan untuk mengidentifikasi dan memanipulasi variabel, menentukan variabel respon dan veriabel kontrol. Selama pelaksanaan eksperimen, siswa juga dapat melihat bagaimana pengaruh variabel manipulasi (bebas) terhadap variabel respon sehingga siswa dapat menguji hipotesis. Hal tersebut sama pada saat siswa-siswa melakukan kegiatan eksperimen dengan menggunakan alat-alat laboratorium KIT IPA sebagai laboratorium yang sebenarnya (real laboratory).

Simulasi PhET sangat mudah untuk digunakan. Simulasi ini ditulis dalam Java dan Flash dan dapat dijalankan dengan menggunakan web browser baku selama plug-in Flash dan Java sudah terpasang. Dengan kata lain, simulasi-simulasi PhET merupakan simulasi yang ramah pengguna. Simulasi-simulasi PhET terdiri dari objek-objek yang tidak terlihat mata di dunia nyata, seperti atom, elektron, foton, dan medan listrik. Siswa dapat melakukan interaksi melalui gambar dan kontrol-kontrol intuitif yang di dalamnya memuat klik dan seret (click and drag), saklar geser dan tombol-tombol. Dengan animasi yang disajikan para siswa dapat menyelidiki sebab dan akibat pada fenomena yang disajikan. Simulasi PhET menekankan hubungan antara fenomena kehidupan nyata dengan ilmu yang mendasari, mendukung pendekatan interaktif dan konstruktivis, memberikan umpan balik, dan menyediakan tempat kerja kreatif (Finkelstein, 2006). Lebih lanjut, Taufiq (2008), simulasi PhET memberikan kesan yang positif, menarik, dan menghibur serta membantu penjelasan secara mendalam tentang suatu fenomena alam. Oleh karena itu, siswa yang berlatih simulasi PhET merasa senang dan mudah untuk mempelajarinya.

Simulasi-simulasi PhET merupakan gambar bergerak (animasi), interaktif dan dibuat seperti layaknya permainan dimana siswa dapat belajar dengan melakukan eksplorasi. Simulasi-simulasi tersebut menekankan korespondensi antara fenomena nyata dan simulasi komputer kemudian menyajikannya dalam model-model konseptual fisis yang mudah dimengerti oleh para siswa. Selama pelaksanaan eksperimen, siswa juga dapat melihat bagaimana pengaruh variabel manipulasi (bebas) terhadap variabel respon sehingga siswa dapat menguji hipotesis. Hal tersebut sama pada saat siswa-siswa melakukan kegiatan eksperimen dengan menggunakan alat-alat laboratorium KIT IPA sebagai laboratorium yang sebenarnya (real laboratory). Simulasi PhET dapat meniru perilaku sistem nyata, suatu strategi pembelajaran yang dapat mempermudah memahami konsep berdasarkan informasi yang terkandung pada rangkaian listrik, menarik, membangkitkan kesadaran tentang konsep atau prinsip, menuntut partisipasi aktif, dan belajar banyak hal (Joyce, dkk; 2009.

Finkelstein, et. al (2004) telah melakukan pengujian efek simulasi komputer sebagai pengganti laboratorium nyata dalam pembelajaran fisika di kelas. Simulasi yang digunakan adalah simulasi arus listrik DC dan dibandingkan dengan menggunakan peralatan laboratorium nyata. Mahasiswa dikelompokkan dalam 3 kelompok, yaitu kelompok yang menggunakan simulasi komputer, kelompok yang menggunakan laboratorium nyata dan kelompok yang sama sekali tidak menggunakan laboratorium. Hasilnya ternyata menunjukkan bahwa mahasiswa yang menggunakan simulasi komputer memiliki pemahaman yang paling unggul secara konseptual dan dapat menerangkan bagaimana sirkuit listrik yang sebenarnya bekerja. Pada tahun berikutnya, Finkelstein, et al (2005), melanjutkan penelitian serupa dengan perlakuan kelompok yang berbeda. Mahasiswa dibagi menjadi 2 kelompok, yaitu mahasiswa yang menggunakan simulasi PhET dan mahasiswa yang menggunakan peralatan laboratorium nyata. Hasilnya ternyata menunjukkan bahwa efek belajar dengan simulasi PhET tetap memberikan hasil yang menakjubkan.

Beberapa prinsip yang perlu diperhatikan guru manakala menggunakan simulasi PhET untuk pembelajaran seperti berikut. (1) Simulasi dilakukan oleh peorangan atau kelompok siswa. Dan penentuan topik disesuaikan dengan tingkat kemampuan kelas, dibicarakan oleh siswa dan guru. (2) Petunjuk simulasi terlebih dahulu disiapkan secara terperinci atau secara garis besarnya, tergantung pada 
bentuk dan tujuan simulasi Dalam kegiatan simulasi hendaknya mencakup semua ranah pembelajaran; baik kognitif, afektif maupun psikomotorik. (3) Hendaknya yang diusahakan terintegrasinya beberapa ilmu. Petunjuk simulasi hendaknya dibuat secara jelas dan mudah dipahami anak. (4) Simulasi penggunaan PhET adalah latihan keterampilan motorik maupun sosial yang dapat memberikan pengalaman belajar bagi siswa dalam menghadapi keadaan yang sebenarnya. (5) Pelaksanaan simulasi perlu menggambarkan situasi yang lengkap, proses yang rinci dan urut yang sesuai dengan situasi yang sesungguhnya. (6) Hendaknya dapat diusahakan terintegrasinya beberapa ilmu, terjadinya proses sebab akibat, pemecahan masalah dan sebagainya.

Hasil penelitian Perkins, et al. (2006) menunjukkan bahwa simulasi-simulasi dalam PhET sangat bermanfaat dalam pembelajaran fisika di kelas. Hasil penelitiannya menunjukkan bahwa $62 \%$ responden menyatakan sangat bermanfaat dalam pembelajaran di kelas dan $22 \%$ responden menyatakan bermanfaat. Lebih lanjut, Sujanem (2013) menunjukkan bahwa hasil belajar listrik siswa SMP Lab Unesa meningkat melalui pembelajaran dengan kegiatan lab menggunakan simulasi PhET.

\section{Metode}

Kegiatan pelatihan dan pendampingan pembuatan media simulasi PhET interaktif pembelajaran Fisika menggunakan pendekatan inkuiri ilmiah ini dilakukan dengan langkah-langkah sebagai berikut.

\section{1) Berkoordinasi dengan MGMP di Kabupaten Buleleng}

Penulis berkoordinasi dengan pengurus MGMP bidang studi Fisika di Kabupaten Buleleng tentang kegiatan P2M yang akan dilaksanakan, seperti: Jenis kegiatan, sasaran kegitan, peserta, tempat dan waktu pelaksanaan. Pada kegiatan koordinasi ini diharapkan akan diperoleh informasi tentang guru-guru yang aktif dan memiliki keterampilan dasar komputear yang memadai. Guru-guru ini selanjutnya menjadi khalayak sasaran dari kegiatan P2M ini. Melalui MGMP, beberapa anggota yang memenuhi kriteria ditunjuk sebagai peserta. Pada kegiatan koordinasi ini juga dijajagi tempat kegiatan pelatihan dan pendampingan. Pengurus dari salah satu MGMP bidang studi diharapkan dapat membantu pelaksana menyiapkan prasarana dan sarana penunjang pelaksanaan kegiatan pelatihan.

\section{2) Pemberian dan pengkajian Materi Pelatihan:}

Materi pelatihan berkaitan dengan pengetahuan dan keterampilan guru IPA bidang fisika daalam pembuatan media simulasi praktikum dengan program simulasi PhET. Untuk komponen pengetahuan akan diberikan materi ajar konsep dasar media dan dasar-dasar pemrograman Simulasi PhET. Untuk komponen keterampilan pembuatan media animasi praktikum IPA dengan simulasi PhET akan diberikan panduan pembuatan media simulasi PhET.

\section{3) Prosedur pelatihan:}

Kegiatan ini direncanakan selama dua bulan untuk pelatihan, dan tiga bulan untuk pendampingan. Kegiatan pelatihan bertujuan untuk memberikan pengetahuan dan keterampilan tentang teori, konsepkonsep dasar media pembelajaran, konsep dasar media simulasi PhET. Pada kegiatan pelatihan, dilaksanakan pada bulan Mei dan Juni 2016. Pada setiap pertemuan, kegiatan diawali dengan kajian konsep-konsep dasar, kemudian dilanjutkan dengan praktek pembuatan media simulasi praktikum IPA SMP. Pada setiap akhir kegiatan, peserta pelatihan diberikan membuat media terkait yang dikaji dan didiskusikan pada pertemuan berikutnya.

Setelah kegiatan pelatihan berakhir, kegiatan dilanjutkan dengan pendampingan implementasi media simulasi praktikum dalam pembelajaran di kelas. Teknis pendampingan, sebagian dilakukan melalui tatap muka dan sebagian dilakukan melalui kegiatan forum diskusi. Untuk teknis tatap muka, kegiatan pendampingan ini dilakukan secara bergiliran pada masing-masing sekolah sesuai dengan jadwal di sekolah masing-masing. Untuk kegiatan tatap muka, sebelum kegiatan implementasi, media simulasi yang akan diimplementasikan didiskusikan kepada narasumber. Selanjutnya, narasumber mencermati media peserta dan memberikan masukan-masukan. Narasumber mengamati implementasi media simulasi PhET, dan memberikan penilaian-penilaian. Pada akhir implementasi media simulasi, dilakukan refleksi dan diskusi membahas pelaksanaan, penyampaian hal-hal yang sudah bagus, dan pemberian saran-saran.

\section{Rancangan Evaluasi}

Evaluasi kegiatan P2M ini dilihat dari dua aspek, yaitu (1) keterlibatan peserta dan (2) output kegiatan. Indikator keberhasilan kegiatan dilihat dari dua komponen evaluasi tersebut. Kegiatan P2M ini menargetkan kehadiran peserta $85 \%$ dari peserta keseluruhan. Output yang ditargetkan adalah dihasilkannya minimal 6 media simulasi praktikum PhET interaktif untuk mendukung pembelajaran 
praktikum IPA bidang fisika. Masing-masing peserta guru dapat mengimplementasikan minimal 2 media simulasi praktikum IPA dalam pembelajaran di kelas.

\section{Hasil dan pembahasan}

Dalam kegiatan pelatihan pembuatan media Simulasi Praktikum IPA SMP dengan Program Simulasi PhET ini, karya utama yang disasar adalah sebagai berikut. 1) Meningkatkan pengetahuan dan keterampilan guru-guru IPA-fisika SMP di kota Singaraja untuk membuat media simulasi PhET untuk pembelajaran interaktif. 2) Guru-guru IPA-fisika SMP di kota Singaraja dapat mengimplementasikan media simulasi PhET dalam proses pembelajaran praktikum fisika di kelas.

Pelatihan dilaksanakan pada bulan Mei dan Juni 2016. Metode pelatihan, para peserta dibekali konsep awal simulasi dengan PhET, diberi contoh cara membuat, dilanjutkan latihan, dan penugasan di rumah dalam waktu satu bulan. Pada pertemuan selanjutnya, dilakukan diskusi sharing pendapat terhadap tugas rumah, kemudian dilanjutkan dengan topic yang baru. Sama seperti pertemuan pertama, peserta dibekali konsep awal simulasi dengan PhET, diberi contoh cara membuat, dilanjutkan latihan, dan penugasan di rumah dalam waktu satu bulan. Hasil-hasil pelatihan pembuatan media Simulasi Praktikum IPA SMP dengan Program Simulasi PhET, seperti ayunan bandul, rangkaian seri, rangkaian parallel, pemantulan cahaya, pembiasan cahaya, dan simulasi partikel penyusun zat. Kegiatan pendampingan pembuatan media simulasi PhET dilakukan pada bulan Agustus 2016, dan peserta pelatihan mengimplementasikan dalam pembelajaran pada bulan September 2016.

Hasil-hasil karya utama dalam pelatihan pembuatan media simulasi dengan program PhET seperti Gambar berikut.

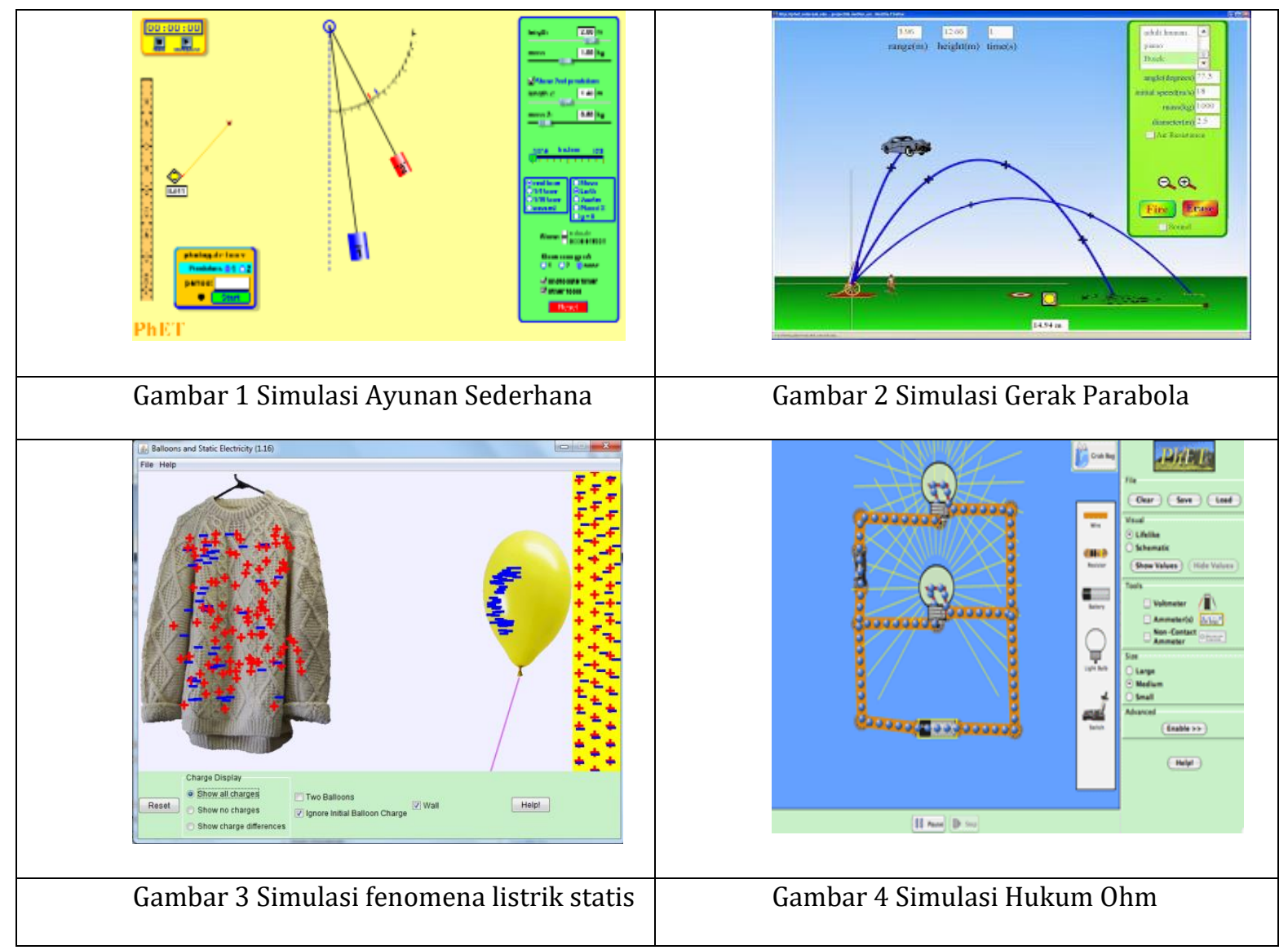




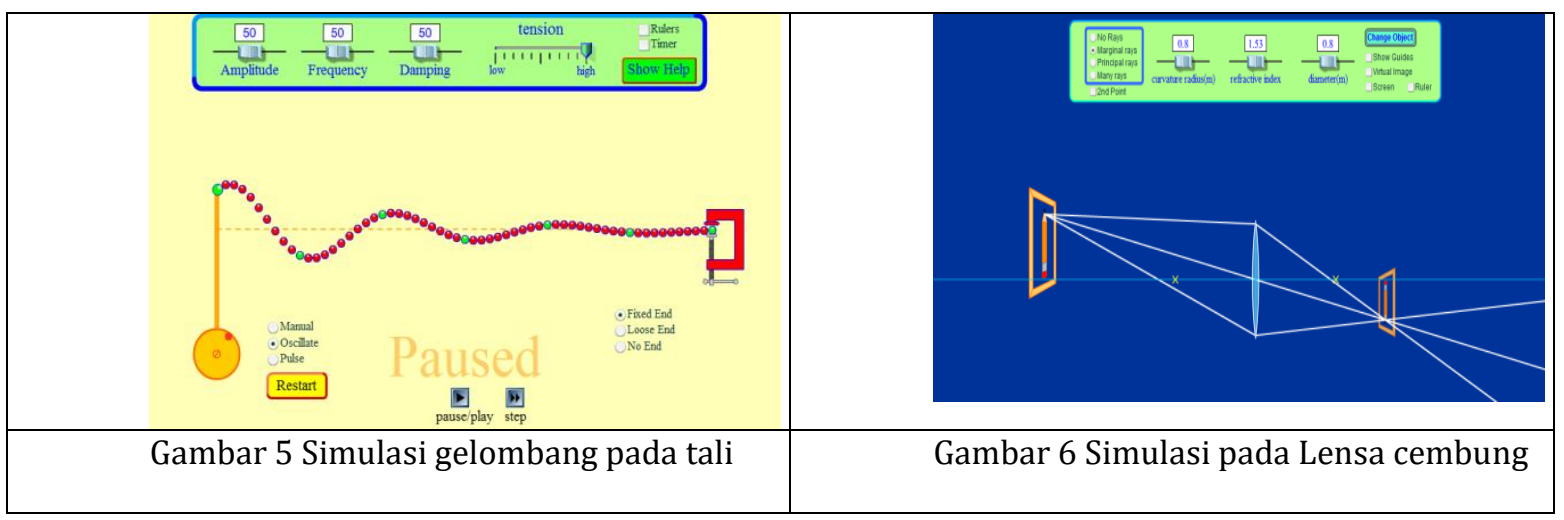

Dalam proses pelatihan pembuatan media simulasi dengan PhET, prosedur yang dilakukan, yaitu pada tahap awal peserta dibekali dengan konsep dasar simulasi dengan program PhET, kemudian peserta diberikan contoh cara-cara pembuatannya. Selanjutnya, peserta diberi kesempatan membuat media sendiri sesuai panduan yang ada, dan bagi yang sudah mampu membuat simulasi, dipersilakn mengembangkan dengan mencari di internet berbagai jenis simulasi yang terkait. Sistem latihan juga ditempuh dengan system tutor teman sebaya sehingga mempercepat proses pencapaian hasil. Di samping itu, para peserta disediakan waktu sekitar satu bulan untuk merancang, membuat, dan menyempurnakan media animasi dengan media PhET ini.

Pada saat pendampingan, peserta mendiskusikan rancangan yang telah dibuat, narasumber mengklarifikasi rancangan apakah nantinya bisa dirancang dalam bentuk media simulasi dengan program PhET. Rancangan tersebut nantinya diimplementasikan saat pembelajaran berlangsung. Pada saat implementasi program pada proses belajar mengajar (praktikum). Dilakukan observasi dan evaluasi untuk dianalisis sejauhmana efektivitas media simulasi praktikum yang dihasilkan dengan simulasi PhET dalam menunjang proses belajar mengajar Fisika. Hasil observasi media simulasi yang dirancang Guru termasuk katagori baik. Hal ini ditunjukkan dengan rancangan yang dibuat telah sesuai dengan konsep fisika, kemenarikan media simulasi, siswa antosias mengikuti pembelajaran. Media simulasi PhET memiliki kepraktisan yaitu mudah dibuat dan diterapkan dalam pembelajaran.

Berdasarkan hasil media simulasi PhET yang sudah diimplementasikan oleh Guru, untuk tahap awal para peserta sudah menghasilkan media simulasi PhET yang sudah baik, namun untuk tahap selanjutnya diharapkan diterapkan pada topic materi yang lain, dan perlu diteliti lebih lanjut keefektifan penggunaan media simulasi praktikum dengan simulasi PhET dalam pembelajaran IPA SMP. Pada akhir kegiatan, dilakukan wawancara kepada perwakilan guru peserta pelatihan terungkap bahwa beberapa orang guru telah menerapkan media simulasi PhET ini, bahkan ada guru peserta yang mengangkat penggunaan media simulasi PhET ini untuk penelitian, namun ada juga guru yang belum menerapkan media ini karena ada beberapa kegiatan di sekolah seperti persiapan dan pelaksanaan ulangan tengah semester, ada sekolah yang mengikuti lomba, dan kegiatan akademik lainnya.

\section{Simpulan dan saran}

Kegiatan P2M penerapan IPTEKS berupa pelatihan dan pendampingan pembuatan media simulasi praktikum IPA dengan program PhET diikuti oleh 15 orang guru IPA SMP di kota Singaraja. Hasil kegiatan P2M ini sesuai dengan tujuan kegiatan, yaitu (1) dapat meningkatkan pengetahuan dan keterampilan guru-guru IPA-fisika SMP di kota Singaraja untuk membuat media simulasi PhET untuk pembelajaran interaktif. (2) Guru-guru IPA-fisika SMP di kota Singaraja dapat mengimplementasikan media simulasi PhET dalam proses pembelajaran praktikum fisika di kelas.

\section{Dampak Dan Manfaat Kegiatan}

Pelatihan dan pendampingan pembuatan midia simulasi dengan program PhET ini berdampak pada pemanfaatan kegiatan lab maya menjadi lebih optimal karena kegiatan laboratorium IPA bidang fisika masih sangat terbatas. Ada beberapa hal penyebab keterbatasan kegiatan laboratorium ini, diantaranya keterbatasan ruang lab, keterbatasan alat lab, alat lab yang mengalami kerusakan, bahkan ruang lab di pakai ruang kelas belajar. Ada tiga manfaat yang diperoleh dari kegiatan P2M ini, yaitu bagi guru, kegiatan P2M ini diharapkan dapat meningkatkan pengetahuan dan keterampilan guru IPA SMP tentang pengembangan media simulasi PhET. Bagi pelaksana, kegiatan P2M memberikan peluang untuk mengabdikan kemampuan dalam simulasi PhET. Simulasi PhET memegang peranan yang sangat penting dalam pembelajaran yang students centered, memiliki keunggulan dalam memudahkan belajar, dan 
adaptable bagi siswa. Bagi Undiksha, kegiatan P2M ini di samping sebagai wujud kepedulian lembaga terhadap permasalahan eksternal dan membangun citra lembaga, UNDIKSHA diharapkan mampu sebagai agent perubahan pendidikan nasional menuju ke arah yang lebih baik melalui penerapan IPTEKS.

\section{Daftar Rujukan}

Arsyad, A. 2005. Media Pembelajaran. Jakarta: PT Raja Grafindo Persada.

Finkelstein, N. 2006. "Hightech Tools For Teaching Physics:The Physics Education Technology Project". Merlot journal of online learning and teaching. Vol. 2 (3): 110-121.

Finkelstein, N.D., Perkins, K.K., Adams, W., Kohl, P., and Podolefsky ,N. 2004. “Can Computer Replace Real Equipment in Undergraduate Laboratories?", Physics Education Research Conference Proceedings. Dapat dinduh di http://www.colorado.edu/physics/EducationIssues/papers/Finkelstein PERC1.pdf

Finkelstein, N.D., Adams, W., Keller, C.J., Kohl, P., and Podolefsky ,N., and S. Reid. 2005. "When learning about the real world is better done virtually: A Study of substituting computer simulation for laboratory equipment". Physical Review Special Topics-Physics Education Research. Dapat diunduh di http://prst-per.aps.org/abstract/PRSTPER/v1/i1/e010103

Joyce, B. Weil, M. Calhoun, E. (2009). Model of Teaching. Alyn and Bacon. United State of America.

Lembaga Pengabdian kepada Masyarakat Undiksha. 2014. Pedoman Kegiatan Pengabdian kepada Masyarakat Undiksha. Singaraja:Undiksha

Perkins, K., Adams, W., Dubson, M., Finkelstein, N., Reid, S. and Wieman, C.. 2006. "PhET: Interactive simulations for Teaching and Learning Physics". The Physics Teacher Vol. 44 Januari 2006.

Permendikbud No 65 Tahun 2013. 2013. Standar Proses Kurikulum 2013. Jakarta: Depdikbud.

Taufiq, M. 2008. Pembuatan Media Pembelajaran Berbasis Compact Disc Untuk Menampilkan Simulasi Dan Virtual Labs Besaran-Besaran Fisika. J. Pijar MIPA. Vol. 3 (3): 68-72. 